\title{
A new species of the Hypostomus cochliodon group (Siluriformes: Loricariidae) from the rio Aripuanã basin in Brazil
}

\author{
Cláudio H. Zawadzki1 and Pedro Hollanda Carvalho²
}

A new species of Hypostomus, H. dardanelos, is described from the rio Aripuanã basin, a southern tributary to the rio Madeira, in northern Mato Grosso State, Brazil. The new species is assigned to the Hypostomus cochliodon group by the possession of few teeth, spoon-shaped teeth, angle between dentaries usually less than $80^{\circ}$, and by the absence of a notch between hyomandibular and the metapterygoid. The new species can be diagnosed from its congeners by its unique color pattern of yellowish-brown ground color covered by well-defined dark spots of relatively equal size, evenly spaced and moderately set along the dorsal region of the body and fins, except on the ventrolateral region of the caudal peduncle and proximal region of anal and caudal fins, which are devoid of spots. The new species is further diagnosed by having teeth with very small lateral cusp, fused to the mesial one and almost imperceptible; by the absence of medial buccal papillae, and by nuptial odontodes all along the body (odontodes more pronounced in some few larger specimens).

Uma espécie nova de Hypostomus, H. dardanelos, é descrita da bacia do rio Aripuanã, um tributário ao sul do rio Madeira, no norte do estado do Mato Grosso, Brasil. A espécie nova é atribuída ao grupo Hypostomus cochliodon por apresentar poucos dentes, dentes em forma de colher, ângulo entre os dentários usualmente menor que $80^{\circ}$ e pela ausência de uma chanfradura entre o hiomandibular e o metapterigoide. A espécie nova pode ser diagnosticada de suas congêneres por seu padrão de cor único marrom-amarelado com pintas escuras bem definidas de tamanho homogêneo, moderadamente distanciadas e igualmente distribuídas ao longo da região dorsal do corpo e nadadeiras, exceto na região ventrolateral do pedúnculo caudal e na região proximal da nadadeira caudal, que são desprovidas de pintas. A espécie nova é adicionalmente diagnosticada por possuir dentes com a cúspide lateral muito reduzida, fundida à cúspide mesial e quase imperceptível; pela ausência da papila bucal medial e por odontódeos nupciais presentes em todo o corpo (odontódeos mais evidentes em alguns poucos exemplares maiores).

Key words: Amazon basin, Catfish, Hypostominae, Neotropical fishes, Taxonomy.

\section{Introduction}

The Hypostomus cochliodon group is a monophyletic lineage (Armbruster \& Souza, 2005), which is widely distributed along most of the main Neotropical river basins. This group encompasses 20 valid nominal species and displays its greatest species richness in the Amazon basin with 15 species (Armbruster, 2003; Hollanda Carvalho \& Weber, 2004; Armbruster \& de Souza, 2005; Hollanda Carvalho et al., 2010). The five remaining non-amazonian species apparently have allopatric distributions. Hypostomus hondae (Regan) is restricted to lake Maracaibo basin and Magdalena, Sinú, and Atrato rivers; H. pagei Armbruster is found in rivers that drain into the Caribbean sea in Venezuela; H. plecostomoides (Eigenmann) is in the Orinoco and Tuy rivers and in the lake Valencia drainage; H. taphorni (Lilyestrom) is only found in the Cuyuni drainage; and finally, H. cochliodon Kner is in rios Paraguay and Paraná basins (Armbruster, 2003).

The rio Aripuanã is a white water tributary to the rio Madeira in the Western Amazon (Goulding et al., 2003). As a southern tributary to the rio Madeira the rio Aripuanã extends more than $1,100 \mathrm{~km}$ from its mouth to its headwaters near the município de Juína in Mato Grosso State. An important and still poorly known component of the Amazonian fish fauna can be found in this system.

${ }^{1}$ Universidade Estadual de Maringá, Departamento de Biologia, Núcleo de Pesquisas em Limnologia, Ictiologia e Aquicultura (Nupélia). Av. Colombo, 5790, 87020-900 Maringá, PR, Brazil. chzawadzki@hotmail.com

${ }^{2}$ Laboratório de Biodiversidade Molecular, Universidade Federal do Rio de Janeiro, Instituto de Biologia, Departamento de Genética. Av. Carlos Chagas Filho s/n - Sala A2-098, 21941-902 RJ, Rio de Janeiro, Brazil. hollandacarvalho@gmail.com 
Ichthyological surveys in the rio Aripuanã and some of its tributaries have recently been carried out. The present work is based on fishes collected from Serra do Expedito, an upland region drained by three right-bank tributaries of the rio Aripuanã. These are the igarapés Rio Claro, Praia Grande and Guaribal, all of which reach the rio Aripuanã downstream the cachoeira Dardanelos. Additional material comes from surveys performed in the region of the rio Aripuanã and its tributaries downstream cachoeira Dardanelos. This paper aims to describe a new species of the Hypostomus cochliodon group found in this region based on its coloration and external morphology.

\section{Material and Methods}

Measurements were taken using a digital caliper to the nearest $0.1 \mathrm{~mm}$. Methodology and terminology of measurements follow Boeseman (1968), modified by Weber (1985) and Zawadzki et al. (2008). Osteological observations were based on the skeleton of one specimen, which was dehydrated in ethanol and cleaned in a dermestarium. Plate counts and nomenclature follow Schaefer (1997), modified by Oyakawa et al. (2005). Standard length (SL) is expressed in millimeters and all other measurements are expressed as percents of standard length or head length (HL), unless otherwise noted. Nontype specimens are conserved in absolute ethanol for further molecular purposes. Considering that low water content ethanol may significantly change body proportion by dehydration we chose not to include these specimens on the type series.

Institutional abbreviations are: AMNH, American Museum of Natural History, New York; ANSP, Academy of Natural Sciences of Drexel University, Philadelphia; AUM, Auburn University Natural History Museum, Auburn; BMNH, Natural History Museum, London; CAS, California Academy of Sciences, San Francisco; FMNH, Field Museum of Natural History, Chicago; INPA, Instituto Nacional de Pesquisas da Amazônia, Manaus; MHNG, Muséum d'histoire naturelle, Geneva; MNRJ, Museu Nacional, Universidade Federal do Rio de Janeiro, Rio de Janeiro; MUSM, Museo de Historia Natural, Universidad Nacional Mayor de San Marcos, Lima; MZUSP, Museu de Zoologia, Universidade de São Paulo, São Paulo; NMW, Naturhistorisches Museum, Vienna; NUP, Coleção Ictiológica do Núcleo de Pesquisas em Limnologia, Ictiologia e Aquicultura, Universidade Estadual de Maringá, Maringá; UMSS, Universidad Mayor de San Simón, Cochabamba; ZMA, Zoologisches Museum, Universiteit van Amsterdam, now in RMNH, Naturalis - National Natuurhistorisch Museum, Leiden; ZSM, Zoologische Staatssammlung München, Munich.

\section{Results}

\section{Hypostomus dardanelos, new species Figs. 1-3}

Hypostomus gr. cochliodon Fernandes et al., 2013: 843 [list of species and ecology].

Holotype. INPA 37342, 172.2 mm SL, Brazil, Mato Grosso State, município de Aripuanã, rio Madeira basin, rio Praia Grande (at its mouth to rio Aripuanã downstream cachoeira Dardanelos and Andorinhas), 1002'51'S 59²3'21”W, 8 Aug 2008, I. M. Fernandes.

Paratypes. All from Brazil, Mato Grosso State, município de Aripuanã, rio Aripuanã basin: MNRJ 36319, 1, 145.5 mm SL, rio Aripuanã, at rapids downstream cachoeira Dardanelos, 1009'41.7'S 59²7'41.9'W, 12 Mar 2008, F. Pupo \& I. Veríssimo. MNRJ 38652, 1, $119.8 \mathrm{~mm} \mathrm{SL}$, rio Aripuanã, left margin, $1500 \mathrm{~m}$ downstream Dardanelos waterfalls, $10^{\circ} 09^{\prime} 30^{\prime}$ S 59²6'19”W, 11 Dec 2008, F. Pupo. MNRJ 38871, 1, $143.0 \mathrm{~mm} \mathrm{SL}$, rio Aripuanã, $500 \mathrm{~m}$ downstream Dardanelos waterfalls, $10^{\circ} 09^{\prime} 47^{\prime \prime} \mathrm{S} 59^{\circ} 26^{\prime} 56^{\prime \prime} \mathrm{W}, 28$ Jul 2010, F. Pupo. MZUSP 37595, 2, 172.0-183.9 mm SL (larger specimen skeletonized after measuring), rio Aripuanã, Humboldt, 3 km downstream Cachoeira Grande falls, no coordinates available, 8 Nov 1976, Expedition MZUSP and INPA. MZUSP 37795, 1, 168.3 mm SL, rio Aripuanã, 8 Nov 1976, Expedition MZUSP and INPA. MZUSP 110798, 2, 135.5-163.7 mm SL, rio Aripuanã, 7 Jan 2004, F. A. Machado, C. M. C. Leite \& F. Rosa. NUP 6758, 8, 118.8$160.5 \mathrm{~mm}$ SL, collected with holotype. NUP 6759, 2, 115.5-141.2 $\mathrm{mm}$ SL, stream with unknown name, tributary to igarapé Guaribal, 1006’35”S 59²6’12”W, 8 Aug 2008, I. M. Fernandes. NUP 6760, 1, $143.5 \mathrm{~mm}$ SL, igarapé Guaribal, tributary to rio Aripuanã, $10^{\circ} 06^{\prime} 35^{\prime}$ 'S 59²6'12”W, 18-19 May 2008, I. M. Fernandes. NUP 6765, 1, 55.0 $\mathrm{mm}$ SL, stream with unknown name, tributary to rio Guaribal, $10^{\circ} 06^{\prime} 35^{\prime}$ 'S 59²6'12”W, 18-19 May 2008, I. M. Fernandes. NUP $6775,1,151.8 \mathrm{~mm}$ SL, stream with unknown name, tributary to rio Praia Grande, $10^{\circ} 02$ '51"S 59²3'21”W, 19 May 2008, I. M. Fernandes. NUP 7098, 1, 46.0 mm SL, stream with unknown name, tributary to igarapé Praia Grande, $10^{\circ} 02^{\prime} 45^{\prime}$ 'S 59²7'24”W, 5 Aug 2008, I. M. Fernandes. NUP 7130, 2, 40.0-42.7 mm SL, stream with unknown name, tributary to igarapé Praia Grande, $10^{\circ} 02$ '59'S 59²7’40”W, 5 Aug 2008, I. M. Fernandes. NUP 7192, 1, 42.0 mm SL, stream with unknown name, tributary to igarapé Rio Claro, 1003'09”S 59॰33'20”W, 6 Aug 2008, I. M. Fernandes. NUP 7474, 4, 123.0-181.0 mm SL, collected with holotype. NUP 7637, 2, 12.3-40.1 mm SL, stream with unknown name, tributary to igarapé Guaribal, 1004'37'S 59³1'04'W, 15 May 2008, I. M. Fernandes. NUP 7694, 1, $42.0 \mathrm{~mm}$ SL, stream with unknown name, tributary to igarapé Guaribal, $10^{\circ} 06$ '35”S 59²6’12”W, 5 Aug 2008, I. M. Fernandes. NUP 9452, 1, 40.6 mm SL, stream with unknown name, tributary to igarapé Rio Praia Grande, $10^{\circ} 02^{\prime} 51^{\prime \prime}$ S 59²3'21”W, 17 May 2008, I. M. Fernandes. 


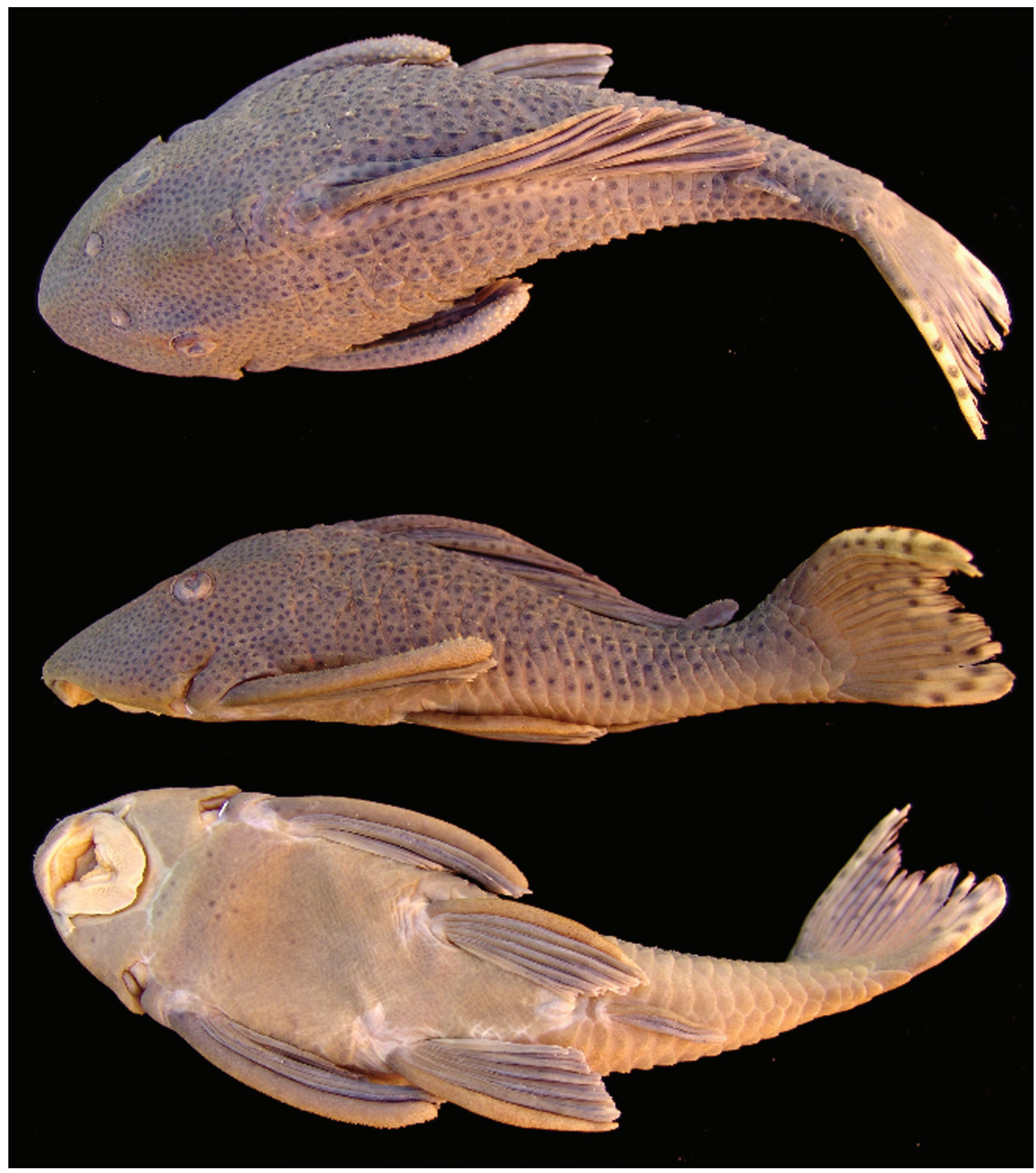

Fig. 1. Hypostomus dardanelos, INPA 37342, 172.2 mm SL, holotype, Brazil, Mato Grosso State, rio Praia Grande, tributary to rio Aripuanã, rio Madeira basin. Picture horizontally reversed.

Non-type specimens. NUP 14655, 1, 103.7 mm SL, Igarapé Arraia, tributary to rio Aripuanã, $10^{\circ} 07^{\prime} 15^{\prime}$ 'S 59॰31'42”'W, 19 Jan 2013, H. P. Silva \& C. H. Zawadzki. NUP 14656, 1, 66.8 mm SL, igarapé Guaribal, tributary to rio Aripuanã, $10^{\circ} 08^{\prime} 51^{\prime \prime}$ 'S 59²9'56”W, 19 Jan 2013, C. H. Zawadzki \& H. P. Silva.
Diagnosis. Hypostomus dardanelos is distinguished from its congeners by its unique color pattern of yellowish-brown ground color covered by well-defined dark spots of relatively equal size, evenly spaced and moderately set along the dorsal region of the body and fins, except on the ventrolateral region 
of the caudal peduncle, and proximal region of anal and caudal fins, which are devoid of spots ( $v s$. without spots, with pale spots, or with moderately- or sparsely-set dark spots that are usually larger, more faded, and more remotely spaced towards posterior region of body, and with ventrolateral caudal peduncle usually bearing spots). Additionally, $H$. dardanelos is further distinguished from all species of Hypostomus, except those belonging to the Hypostomus cochliodon group, by having few spoon-shaped teeth, 10 to 13 (vs. more than 16 villiform teeth), dentaries angled less than $80^{\circ}$ (vs. dentaries angled more than $80^{\circ}$ ) and by the presence of a notch between hyomandibular and the metapterygoid ( $v s$. notch absent). The new species is further diagnosed from $H$. hemicochliodon Armbruster, H. kopeyaka Carvalho, Lima \& Zawadzki, $H$. sculpodon Armbruster, H. soniae Hollanda Carvalho \& Weber, and $H$. weberi Hollanda Carvalho, Lima \& Zawadzki by

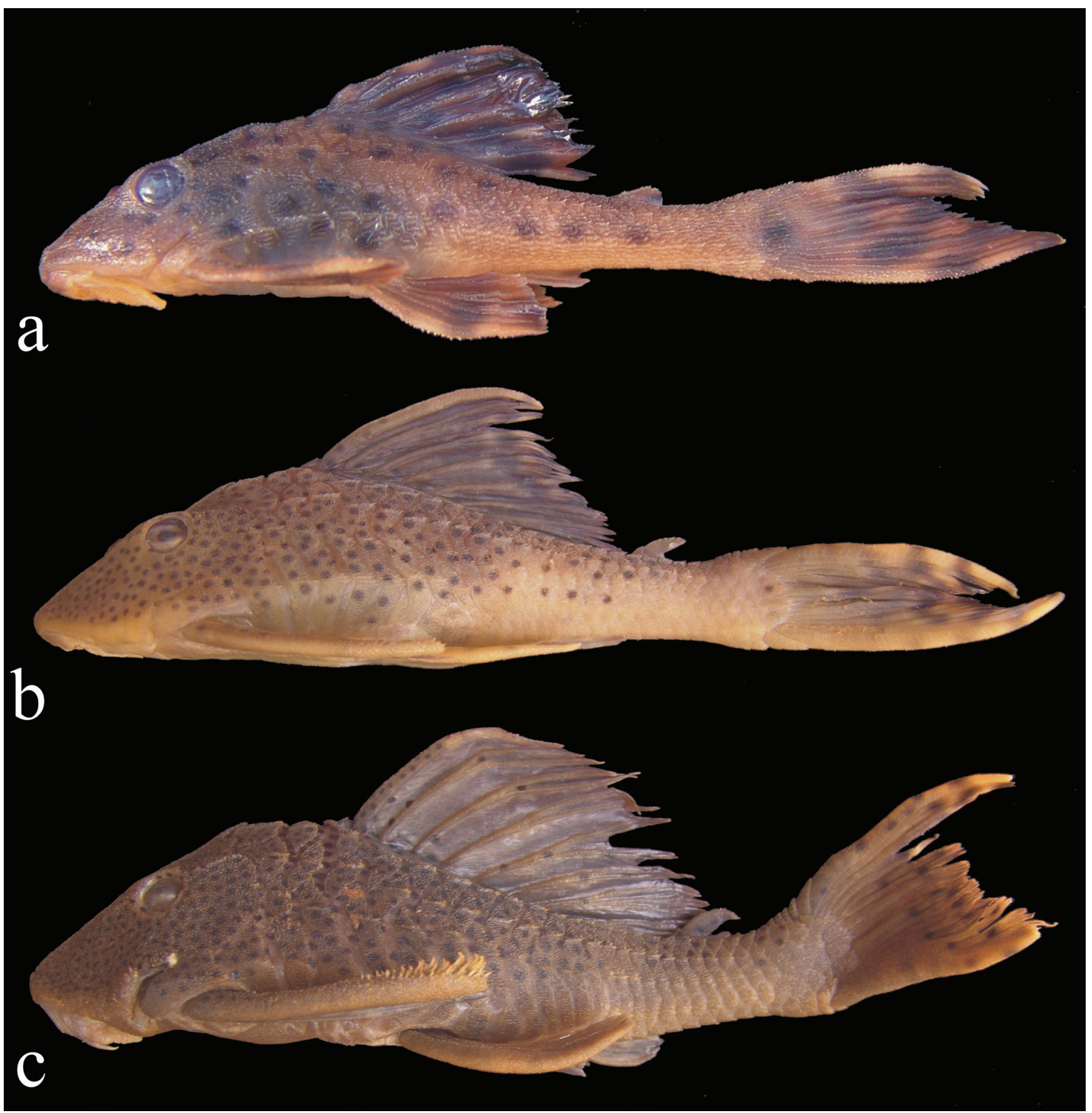

Fig. 2. Specimens of Hypostomus dardanelos showing ontogenetic variation on the color pattern and on the development of the nuptial body odontodes in c. (a) NUP 7098, paratype, $46.0 \mathrm{~mm}$ SL; (b) NUP 6759, paratype, $115.5 \mathrm{~mm}$ SL; and (c) NUP 7474, paratype, $181.0 \mathrm{~mm}$ SL. 
possessing massive round teeth, with mesial cusp large and distinctly spoon shaped and outer cusp, if present, fused to the mesial one and scarcely noticeable ( $v s$. clearly bicuspid teeth, although the lateral cusp is considerably smaller than mesial cusp); from $H$. hemicochliodon, H. kopeyaka, H. paucimaculatus Boeseman, H. sculpodon, H. waiampi Hollanda Carvalho \& Weber, $H$. weberi by lacking a medial buccal papilla ( $v s$. medial buccal papilla present); from $H$. ericae Hollanda Carvalho \& Weber, H. plecostomoides, and $H$. pyrineusi (Miranda Ribeiro) by having strong keels in dorsal, mid-dorsal and median series of plates ( $v s$. keels absent in $H$. pyrineusi and moderately-developed keels in $H$. ericae and $H$. plecostomoides); from H. ericius Armbruster by having caudal fin usually with dark spots distally ( $v s$. caudal fin dark blurred distally); from $H$. hondae by having the exposed portion of opercle inconspicuous ( $v s$. exposed portion of opercle easily visualized); from $H$. macushi Armbruster \& Souza by having small dark spots (vs. medium to large dark spots); from $H$. oculeus (Fowler) by lacking strong keel on mid-ventral series of plates ( $v s$. having strong keels on all lateral series plates, including the mid-ventral one, see Armbruster, 2003, fig. 16); from $H$. pagei by having uniformly conspicuous small dark spots ( $v s$. spots becoming faded or absent); and from $H$. taphorni by having both caudal-fin lobes evenly colored ( $v s$. bicolored caudal fin with lower lobe darker).

Description. Meristic and morphometric data in Table 1. Holotype and additional specimens in Figs. 1-3. Dorsal profile slightly convex to straight from snout tip to interorbital area, strongly convex from interorbital area to dorsal-fin origin, and gently descending from dorsal-fin origin to first procurrent plate of caudal fin. Ventral profile almost straight from snout tip to caudal fin. Caudal peduncle slightly compressed laterally, ellipsoid in cross section. Body width at cleithral region greater than head depth. Head broad and deep, dorsally covered with dermal bones, except for small naked area on snout tip (snout tip plated in one specimen, NUP 7474, $181.0 \mathrm{~mm} \mathrm{SL}$ ). Median elongated bulge associated with mesethmoid terminating coequally with transversal through nares. Conspicuous ridge originating lateral to nares, passing through supraorbital, and extending to posterior portion of pterotic-supracleithrum. Supraoccipital bone with moderate to highly developed median ridge, and with relatively well-developed posterior process bordered by single wide plate. Exposed region of opercle small, not easily seen and usually with less than ten odontodes. Oral disk round, moderate in size. Lower lip not reaching transversal through gill openings, ventral surface covered with numerous small papillae decreasing in size posteriorly. Maxillary barbel moderately developed, almost equal in length to orbital diameter. Odontodes present over anterior surface of upper lip, just below snout. Medial buccal papillae absent. Maxilla straight. Jaws acutely angled, averaging less than

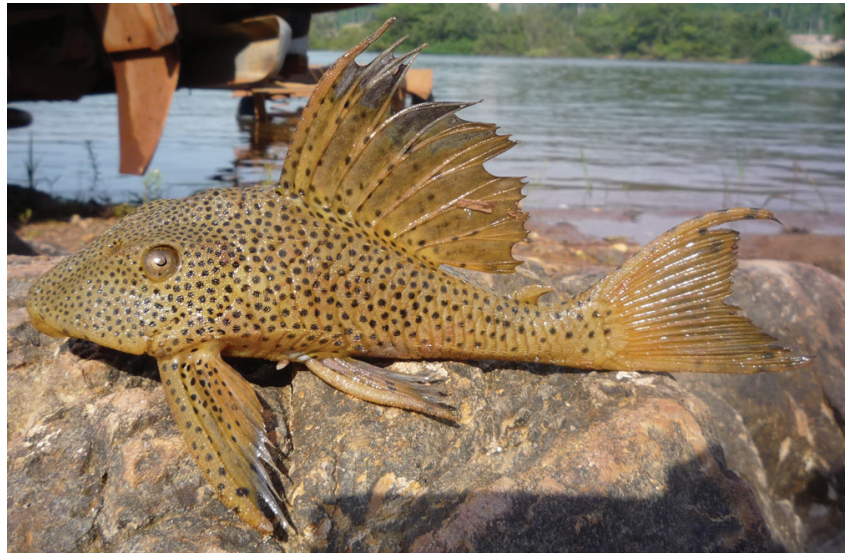

Fig. 3. Live specimen of Hypostomus dardanelos, MNRJ 36319 , paratype, $145.5 \mathrm{~mm} \mathrm{SL}$, from the rio Aripuanã at the rapids downstream cachoeira Dardanelos, município de Aripuanã, Mato Grosso State, Brazil. Photographed immediately after capture by F. Pupo.

$80^{\circ}$ between left and right dentary rami. Teeth spoon shaped, apparently unicuspid; mesial cusp massive and round; lateral cusp extremely reduced and usually fused to mesial cusp (similar to the condition found in Hypostomus ericae; Hollanda Carvalho \& Weber, 2004: 640, fig. 4a).

Body covered with five rows of moderately spinulose dermal plates, except for region surrounding dorsal-fin base and very small areas around pectoral- and pelvic-fin insertions and at urogenital opening. Specimen NUP 7474, $181.0 \mathrm{~mm}$ SL with well-developed nuptial odontodes along dorsal surface of body and fin rays (Fig. 2c). Predorsal region with two conspicuous keels; area between keels flat. Dorsal, middorsal, and median series of plates with keels supporting sharp odontodes. Mid-ventral series lacking sharp odontodes or having moderate odontodes. Dorsal series of lateral plates with keel from first plate to area just anterior to origin of adipose fin. Mid-dorsal series of lateral plates with keels from first plate to area just posterior to adipose fin; third plate with keel oriented upward. Median series of plates with moderately-developed keels to area just below posterior dorsal-fin base. Mid-ventral series of plates with moderate keels from first to fifth or sixth plate, then slightly arched to area below adipose fin. Ventral series of plates devoid of keels; posterior two plates deflected laterally. Ventral surface of head totally covered with platelets, except for region beneath lower lip. Abdomen completely covered with minute platelets in specimens larger than 120 $\mathrm{mm}$ SL. Preanal plate present.

Dorsal fin II,7, its origin at vertical through midpoint between origins of pectoral and pelvic fin, or slightly posterior to that point. Dorsal-fin margin straight to slightly convex. Adipose-fin spine compressed and curved toward its base. Pectoral fin I,6, its posterior border straight. Pectoral-fin spine slightly curved posteriorly, covered with moderately 
developed odontodes; odontodes enlarged towards distal portion of spine and particularly in larger specimens. Specimen NUP 7474, $181.0 \mathrm{~mm}$ SL with strong hypertrophied odontodes on posterodorsal region of pectoral fin. Tip of adpressed pectoral fin reaching to anterior one-third of pelvic-fin spine length. Pelvic fin i,5, its posterior border slightly roundish. Adpressed pelvic-fin spine just reaching to or just surpassing anal-fin origin. Anal fin i,4, its tip reaching the fifth to sixth plate after its origin. Rays of anal fin progressively increasing in size, third branched ray usually the longest. Caudal fin i,14,i. Caudal-fin margin falcate; ventral lobe slightly longer than dorsal one.

Color in alcohol. Overall ground color of dorsal and ventral regions of body and fins yellowish-brown. Dorsal surface of head and body covered by well-defined and moderately-set dark spots except on ventrolateral region of caudal peduncle. Spots on ventral surface uncommon, observed only in two specimens as scarce and sparsely arranged. Dorsal and pectoral fins with dark spots, mainly on proximal region and along spines and first branched rays. Pelvic fin with dark spots usually grouped on median region of branched rays. Anal fin usually lacking spots. Caudal fin with few distally, but usually lacking spots proximally; distal caudal-fin spots occasionally vertically aligned in two to three bands.

Spot pattern with pronounced ontogenetic variation (Fig. 2). Marks typically larger, scarce and ill-defined on smaller specimens. Patches of pigmentation gradually forming welldefined spots during ontogenic growth. Dark spots generally large, few in number and widely spaced on specimens up to $45 \mathrm{~mm} \mathrm{SL}$; spots on fins sometimes fused forming transverse bands. Spots smaller, mores numerous and set closer on specimens up to $115 \mathrm{~mm} \mathrm{SL}$. Spots better outlined at this stage, especially on head and trunk. Spots progressively more numerous on head and trunk, and better outlined, including fins, up to specimens around $180 \mathrm{~mm} \mathrm{SL}$.

Color in life. Live specimens with coloration similar to preserved ones, except for more brownish yellow coloration on body and fins (Fig. 3).

Table 1. Morphometric data and counts of Hypostomus dardanelos.

\begin{tabular}{|c|c|c|c|c|}
\hline & & \multicolumn{3}{|c|}{22 specimens } \\
\hline & & Holotype & Range & Mean/SD \\
\hline \multirow[t]{2}{*}{ Standard length } & & 172,2 & $114.8-183.9$ & $151.1 \pm 18.51$ \\
\hline & Percents of standard length & & & \\
\hline Predorsal length & & 42.0 & $38.2-42.0$ & $40.1 \pm 1.03$ \\
\hline Head length & & 33.1 & $31.3-34.2$ & $32.6 \pm 0.68$ \\
\hline Cleithral width & & 32.0 & $29.7-32.5$ & $31.2 \pm 0.76$ \\
\hline Head depth & & 25.2 & $22.2-25.2$ & $23.8 \pm 0.77$ \\
\hline Interdorsal length & & 17.7 & $15.1-19.2$ & $17.6 \pm 1.34$ \\
\hline Caudal-peduncle length & & 32.0 & $29.7-35.9$ & $32.2 \pm 1.73$ \\
\hline Caudal-peduncle depth & & 10.6 & $9.5-12.0$ & $10.6 \pm 0.61$ \\
\hline Dorsal-fin spine length & & 27.4 & $27.2-34.4$ & $31.0 \pm 2.24$ \\
\hline \multirow[t]{2}{*}{ Thoracic length } & & 24.8 & $22.6-25.5$ & $24.1 \pm 0.86$ \\
\hline & Percents of head length & & & \\
\hline Cleithral width & & 96.7 & $92.2-100.2$ & $95.7 \pm 2.13$ \\
\hline Head depth & & 76.2 & $69.2-76.2$ & $72.8 \pm 2.02$ \\
\hline Snout length & & 66.0 & $62.2-69.2$ & $66.2 \pm 2.05$ \\
\hline Orbital diameter & & 17.3 & $16.5-19.3$ & $17.8 \pm 0.85$ \\
\hline Interorbital width & & 49.5 & 46.4-53.7 & $51.1 \pm 1.79$ \\
\hline \multirow[t]{2}{*}{ Mandibullary width } & & 13.0 & $12.7-15.4$ & $13.7 \pm 0.65$ \\
\hline & Other percents & & & \\
\hline Orbital diameter in snout length & & 26.3 & $24.0-29.4$ & $26.9 \pm 1.51$ \\
\hline Orbital diameter in interorbital width & & 35.0 & $33.2-37.8$ & $34.9 \pm 1.54$ \\
\hline Mandibulary width in interorbital width & & 26.3 & $24.8-29.4$ & $26.8 \pm 1.23$ \\
\hline First dorsal fin ray length in predorsal length & & 65.3 & $65.3-86.4$ & $76.9 \pm 6.23$ \\
\hline First pectoral ray length in predorsal length & & 79.5 & $75.1-85.6$ & $82.0 \pm 2.90$ \\
\hline Lower caudal ray length in predorsal length & & - & $62.6-98.6$ & $82.9 \pm 9.38$ \\
\hline Adipose ray length in caudal peduncle depth & & 69.3 & $57.8-75,8$ & $65.9 \pm 6.10$ \\
\hline Caudal peduncle depth in Caudal peduncle length & & 33.1 & $27.0-38.0$ & $33.1 \pm 2.84$ \\
\hline Mandibulary width in cleithral width & & 13.4 & $13.3-15.8$ & $14.3 \pm 0.67$ \\
\hline Interdorsal length in dorsal base length & & 63.2 & $50.4-69.1$ & $60.6 \pm 6.11$ \\
\hline Lower lip length in lower lip width & & 31.2 & $26.8-38.3$ & $33.8 \pm 3.51$ \\
\hline Counts & & Holotype & Range & Mode \\
\hline Median plate series & & 25 & $25-27$ & 27 \\
\hline Predorsal plates & & 3 & $3-3$ & 3 \\
\hline Dorsal plates below dorsal-fin base & & 9 & $8-9$ & 8 \\
\hline Plates between dorsal and adipose fin & & 7 & $6-8$ & 7 \\
\hline Plates between adipose and caudal fin & & 4 & $4-8$ & 6 \\
\hline Ventral plates between end of anal-fin base and caudal fin & & 12 & $12-14$ & 13 \\
\hline Premaxillary teeth & & 11 & $8-14$ & 11 \\
\hline Dentary teeth & & 10 & $9-15$ & 13 \\
\hline
\end{tabular}


Distribution. Hypostomus dardanelos is currently known from the rio Aripuanã drainage, downstream cachoeira Dardanelos (Fig. 4).

Etymology. The specific epithet, dardanelos, is a noun in reference to the cachoeira Dardanelos. A noun in apposition.

\section{Discussion}

The unique pattern of spots exhibited by Hypostomus dardanelos allows a prompt identification of this species. The most typical pattern among Hypostomus and other species of Hypostominae is characterized by dark spots covering the whole dorsal surface of the body, and these spots become fainter and more widely spaced as approach the caudal fin. The color pattern displayed by $H$. dardanelos differs from the pattern detailed above due to be distinctly outlined, unvarying in size and having evenly spaced spots present throughout the whole dorsal surface of the body. Also the spots on the caudal peduncle are clearly restricted to its dorsolateral region. The unspotted area on the caudal peduncle is the most striking trait of this particular pattern. The species most similar to H. dardanelos are H. ericae (Fig. 5a), which inhabits the rio Tocantins-Araguaia basin in Tocantins State, Brazil and H. ericius (Fig. 5b), from the upper Amazon basin in Peru. However, H. ericae lacks strong keels supporting odontodes along lateral series of plates (vs. keels present on both $H$. dardanelos and $H$. ericius). The caudal fin is usually devoid of spots on its proximal region in H. dardanelos, in H. ericae, and in H. ericius. However, the caudal fin is usually spotted on the distal region in $H$. dardanelos and in $H$. ericae, while in $H$.

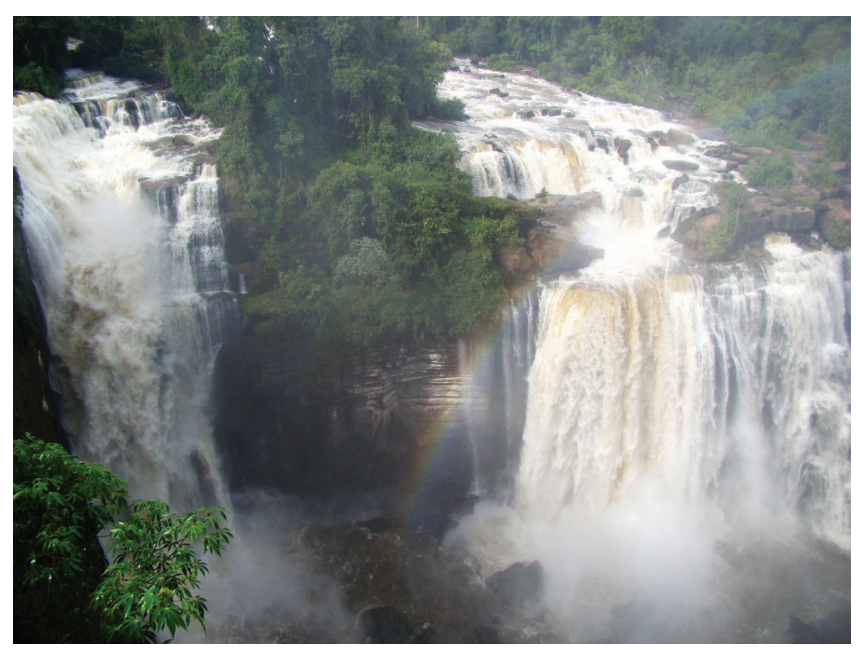

Fig. 4. The cachoeira Dardanelos at the município de Aripuanã, Mato Grosso State, Brazil. This fall is part of a series of close waterfalls descending about $150 \mathrm{~m}$ from its upper to the lower levels. This natural feature is known to be a biogeographic boundary for certain groups of fishes. ericius the caudal fin color pattern is commonly dark blurred on the distal region (Fig. 5b). In addition to the characters already described, another diagnostic feature is recognized. The presence of dark spots on the ventral surface is the common condition in H. ericius (see Armbruster, 2003) and in H. ericae (see Hollanda Carvalho \& Weber, 2004), while it is uncommon in $H$. dardanelos.

Among the Amazonian species of the Hypostomus cochliodon group, two of them are from the rio Madeira basin. Hypostomus levis (Pearson) was described from Cochabamba and Popoi rivers, upper rio Madeira basin, in Bolivia, and $H$. pyrineusi is uncertainly assigned to the rio Jamari (Weber, 2003) in Brazil. Hypostomus dardanelos is distinguished from both species by the unspotted ventrolateral region of caudal peduncle, by having conspicuous keels supporting odontodes along the lateral series of plates and by a ridge on the pterotic supracleithrum (vs. absent in H. levis and $H$. pyrineusi). The presence of an adipose fin also differs $H$. dardanelos from $H$. levis.

According to Kullander (1995), some fishes appear to be endemic to the rio Aripuanã drainage, and recent publications have assigned new species to this basin. Rocha et al. (2008a, 2008b) described two siluriforms from the middle portion of the rio Aripuanã, Gladioglanis anacanthus and Scoloplax baskini, respectively. Zanata \& Ohara (2009) described a new characin, Jubiaba citrina from the middle portion of the river, and cited that this species is probably endemic to the rio Aripuanã basin.

Most specimens of Hypostomus dardanelos were found in the rivers draining from the Serra do Expedito in the middle portion of the rio Aripuanã basin. The igarapés Guaribal, Praia Grande and rio Claro drain the Serra do Expedito into the right bank of the upper rio Aripuanã. One striking feature upstream of the confluence of these three tributaries is the cachoeira Dardanelos, a series of close waterfalls descending a total of $150 \mathrm{~m}$ (Fig. 4). This remarkable geographic feature is a clear divide for certain groups of fishes inhabiting the rio Aripuanã basin. There are some species of fish (e.g., the cichlids, Aequidens gerciliae Kullander, Crenicichla hemera Kullander, C. isbrueckeri Ploeg, and C. pellegrini Ploeg, and the anostomid Leporinus trimaculatus Garavello \& Santos) that are considered endemic to the upper rio Aripuanã basin above the cachoeira Dardanelos (Kullander, 1995). On the other hand, several other fish species seem to be restricted to downstream cachoeira Dardanelos, as the loricariid Parotocinclus aripuanensis Garavello described from the rio Canumã, which joins rio Aripuanã just downstream of those falls. Despite recent collection efforts, H. dardanelos has not been recorded above the cachoeira Dardanelos.

Comparative material. Hypostomus cochliodon. Brazil. NMW 44101, 1, 176.2 mm SL, syntype, rio Cuiabá. NUP 9822, 6, 26.8-143.0 


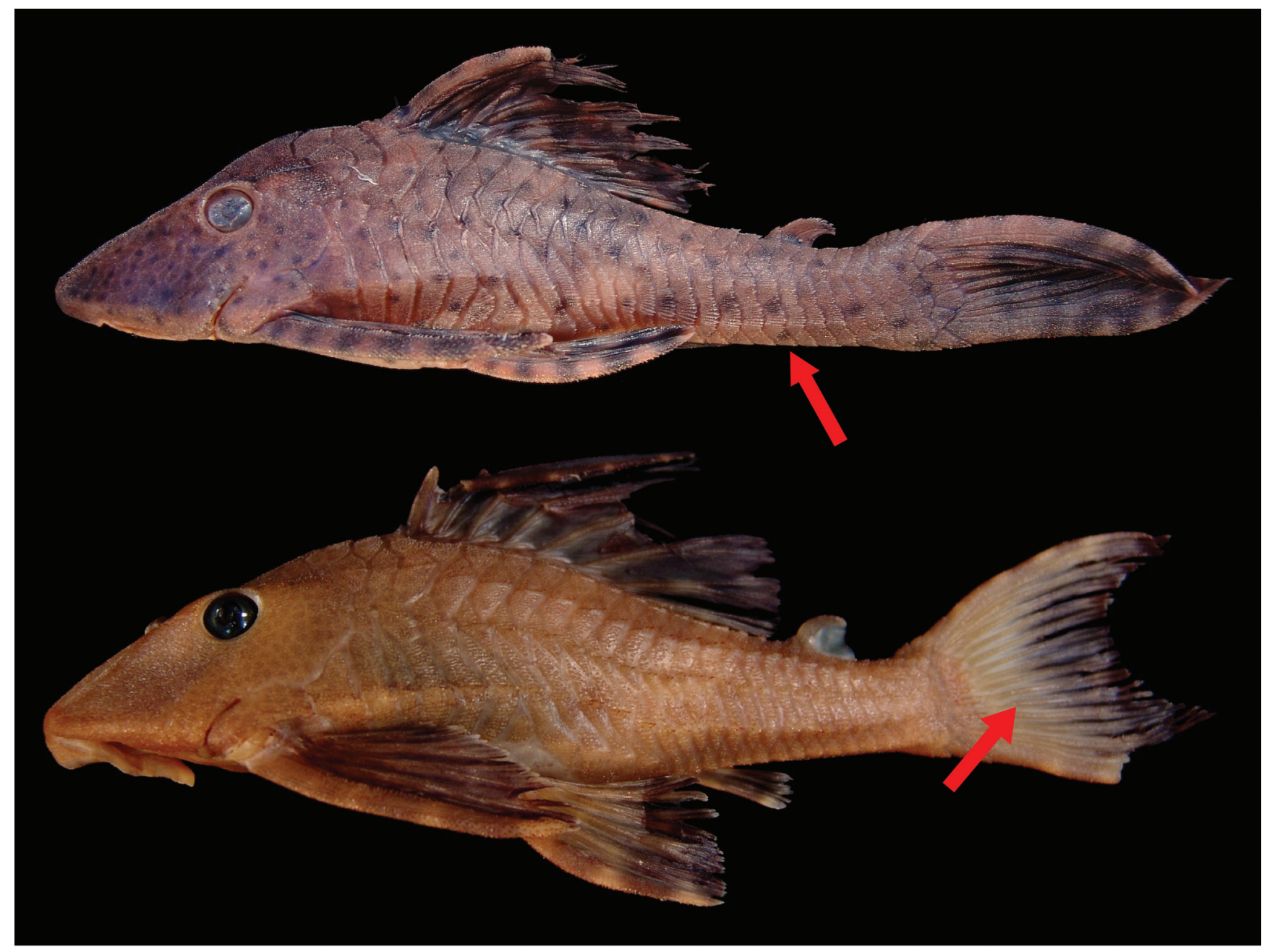

Fig. 5. Hypostomus ericae NUP 6436, 155.6 mm SL; Brazil, Mato Grosso State, Barra do Garça, rio Araguaia basin, córrego Fundo (a); Hypostomus ericius MUSM 27553, 118.9 mm SL: Peru, Ucayali Department, río Breu basin, río Yrua (b). Red arrows highlight the spotted ventrolateral region of caudal peduncle in $H$. ericae and the caudal fin dark blurred distally in $H$. ericius.

mm SL, córrego da Onça. NUP 10807, $208.0 \mathrm{~mm}$ SL, rio Manso. NUP 11956, 5, 38.6-92.8 mm SL, córrego Palmeira. NUP 12000, 2, 155.8-174.1 mm SL, rio Cuiabá. NUP 12001, 1, $202.8 \mathrm{~mm} \mathrm{SL}$, rio Manso. Hypostomus ericae. Brazil. MHNG 2650.026, 1, 130.5 mm SL, paratype, rio Maranhão. MNRJ 27861, 1, 164.3 mm SL, holotype, rio Tocantins. NUP 6436, 1, 155.4 mm SL, córrego Fundo. NUP 8298, 1, 53.0 mm SL, stream with unknown name. Hypostomus ericius. Peru. AMNH 218035, 1, 85.3 mm SL, paratype, upper río Amazon. ANSP 176149, 1, 104.0 mm SL, paratype, río Nanay. MUSM 27553, 1 of 4, $110.0 \mathrm{~mm}$ SL, río Breu. Hypostomus fonchii. Peru. MHNG 2613.066, 1, 141.0 mm SL, holotype, río Cushabatay basin. Hypostomus hemicochliodon. Ecuador. FMNH 106021, 2, 31.0-106.0 mm SL, rio Payamino. FMNH 106024, 1, 159.0 mm SL, rio Payamino. Venezuela. ANSP 185320, $228.0 \mathrm{~mm}$ SL, Crano Grula, tributary to río Orinoco. Hypostomus hondae. Colombia. AMNH 12599, 1, 124.0 mm SL, río Macauá. BMNH 1909.7.23.44, 1, 59.1 mm SL, paratype. SU 50373, 1, 106.0 mm SL, rio Samana, rio Magadalena basin. SU 56863. Venezuela. CAS 136504, 2, 50.059.7 mm SL, río Monay. Hypostomus kopeyaka. Brazil. MZUSP 98764, 1, 226.1 mm SL, holotype, rio Tiquié. NUP 8019, 1, 140.4 mm SL, igarapé Castanha, tributary of rio Tiquié. Hypostomus levis. Bolivia. UMSS 1721, $187.9 \mathrm{~mm}$ SL, río Paraguá. Hypostomus macushi. Venezuela. AUM 35510, 1, 148.1 mm SL. AUM 45064, 1, 170.0 mm SL. Hypostomus oculeus. Colombia. FMNH 106015, 1, 130.0 mm SL, río Aguarico. FMNH 106016, 3, 52.0-183.0 mm SL, río Payamino. Hypostomus pagei. Suriname. ZMA 109.982, 1, $189.2 \mathrm{~mm}$ SL, Wilhelmina mountains. Hypostomus paucipunctatus. Brazil. MHNG 2652.017, 2, 135.6-155.0 mm SL, paratypes, rio Itacaiúnas. MZUSP 82271, 1, 177.1 mm SL, holotype, rio Itacaiúnas. Hypostomus plecostomoides. Venezuela. ANSP 166889, 1, $215.0 \mathrm{~mm}$ SL, río Orinoco. ANSP 180718, 2, 38.6-175.0 mm SL, río Inambari. CAS 12694, 1, 214.0 mm SL, río Bue. Hypostomus pyrineusi. Bolivia. ZSM 22025, 2, 241.6-241.7 mm SL, río Chipiriri. Brazil. MNRJ $863,1,204.0 \mathrm{~mm}$ SL, holotype, probably rio Jamari. MNRJ 31899 , 
1, 176.7 mm SL, rio Urupá, rio Machado basin. NUP 10047, 1, 150.3 mm SL, rio Jaciparaná, rio Madeira basin. NUP 10984, 2, 168.9-169.9 $\mathrm{mm}$ SL, ribeirão Xambioazinho, rio Tocantins-Araguaia basin. Peru. FMNH 97017, 3, 76.0-132.0 mm SL, rio Marañon. FMNH 113911, 1, 126.0 mm SL, Loreto. Hypostomus simios. Brazil. MHNG 2652.018, 1, $112.0 \mathrm{~mm}$ SL, paratype, rio Cupixi. MZUSP 82268, 1, $157.9 \mathrm{~mm}$ SL, holotype, rio Cupixi. Hypostomus sculpodon. Venezuela. AUM 39476, 1 of 2, $220.0 \mathrm{~mm}$ SL. AUM 40220, 1, $229.0 \mathrm{~mm}$ SL. AUM 42188, 4 of 7, 219.0-264.0 mm SL. Hypostomus soniae. Brazil. MHNG 2547.012, 13, 35.4-143.0 mm SL, paratypes, rio Tapajós. MNRJ 35619, 10 of 38, 97.4-163.7 mm SL, rio Cristalino, rio Tapajós basin. NUP 13394, 1, $143.3 \mathrm{~mm} \mathrm{SL}$, córrego do Valdir, tributary to rio Teles Pires. Hypostomus taphorni. Venezuela. AMNH 13664, 1, 189.0 mm SL, Essequibo River. Hypostomus waiampi. Brazil. MHNG 2652.016, 1, 174.4 mm SL, paratype, rio Cupixi. Hypostomus weberi. Brazil. MZUSP 98767, 1, $149.3 \mathrm{~mm}$ SL, holotype, rio Negro. NUP 6344, 1, 156.6 mm SL, paratype, rio Marauiá.

\section{Acknowledgments}

The authors are grateful to Rafaela Ota (INPA), Renildo Ribeiro (INPA), and Mark Sabaj Pérez (ANSP) for comments and suggestions on the manuscript. We also thank Izaias Fernandes for leading the sampling efforts at the Serra do Expedito in the rio Aripuanã, and Fábio Pupo (MNRJ) for sending the specimens and the photos of the live specimen (Figure 3). Thanks to Barbara Brown and Scott Schaefer (AMNH), Mark Sabaj Pérez (ANSP), Jonathan Armbruster (AUM), Patrick Campbell (BMNH), David Catania and Tomio Iwamoto (CAS), Mary Anne Rogers and Kevin Swagel (FMNH), Lucia Rapp Py-Daniel and Renildo Ribeiro (INPA), Claude Weber and Sonia Fisch-Muller (MHNG), Patrice Pruvost (MNHN), Paulo Buckup and Marcelo Britto (MNRJ), Hernán Ortega (MUSM), Osvaldo Oyakawa (MZUSP), Ernst Mikschi and Helmut Wellendorf (NMW), Ronald Vonk and Ronald de Ruiter (ZMA), Dirk Neumann (ZSM) and Fernando Carvajal (UMSS) for loan of comparative material and hosting museum visits. The English revision of the text was performed by Carla Zilberberg (UFRJ). Nupélia and MZUSP provided logistical support. This study was partially supported by awards to CHZ from the Planetary Biodiversity Inventory: All Catfish Species (Siluriformes) - Phase I of an Inventory of the Otophysi (US National Foundation DEB-0315963). CHZ was funded by Conselho Nacional de Desenvolvimento Científico e Tecnológico (CNPq Proc. 310733/2013-8).

\section{Literature Cited}

Armbruster, J. W. 2003. The species of the Hypostomus cochliodon group (Siluriformes: Loricariidae). Zootaxa, 249: 1-60.
Armbruster, J. W \& L. S. Souza. 2005. Hypostomus macushi, a new species of the Hypostomus cochliodon group (Siluriformes: Loricariidae) from Guyana. Zootaxa, 920: 1-12.

Boeseman, M. 1968. The genus Hypostomus Lacépède, 1803, and its Surinam representatives (Siluriformes: Loricariidae). Zoologische Verhandelingen, 99: 1-89.

Fernandes, I. M., L. S. Lourenço, R. P. Ota, M. M. M. Moreira \& C. H. Zawadzki. 2013. Effects of local and regional factors on the fish assemblage structure in Meridional Amazonian streams. Environmental Biology of Fishes, 96: 837-848.

Goulding, M. R., R. Barthem \& E. Ferreira. 2003. The Smithsonian atlas of the Amazon. Washington, Smithsonian Books.

Hollanda Carvalho, P., F. C. T. Lima \& C. H. Zawadzki. 2010. Two new species of the Hypostomus cochliodon group (Teleostei: Loricariidae) from the rio Negro in Brazil. Neotropical Ichthyology, 8: 39-48.

Hollanda Carvalho, P. \& C. Weber. 2004. Five new species of the Hypostomus cochliodon group (Siluriformes: Loricariidae) from middle and lower Amazon System. Revue suisse de Zoologie, 111: 953-978.

Kullander, S. O. 1995. Three new cichlid species from southern Amazonia: Aequidens gerciliae, A. epae and A. michaeli. Ichthyological Exploration of Freshwaters, 6: 149-170.

Oyakawa, O. T., A. Akama \& A. M. Zanata. 2005. Review of the genus Hypostomus Lacépède, 1803 from rio Ribeira de Iguape basin, with description of a new species (Pisces, Siluriformes, Loricariidae). Zootaxa, 921: 1-27.

Rocha, M. S., R. R. de Oliveira \& L. R. Py-Daniel. 2008a. A new species of Gladioglanis Ferraris \& Mago-Leccia from rio Aripuanã, Amazonas, Brazil (Siluriformes: Heptapteridae). Neotropical Ichthyology, 6: 433-438.

Rocha, M. S., R. R. de Oliveira \& L. R. Py-Daniel. 2008b. Scoloplax baskini: a new spiny dwarf catfish from rio Aripuanã, Amazonas, Brazil (Loricarioidei: Scoloplacidae). Neotropical Ichthyology, 6: 323-328.

Schaefer, S. A. 1997. The Neotropical cascudinhos: systematics and biogeography of the Otocinclus catfishes (Siluriformes: Loricariidae). Proceedings of the Academy of Natural Sciences of Philadelphia, 148: 1-120.

Weber, C. 1985. Hypostomus dlouhyi, nouvelle espèce de poisson-chat cuirassé du Paraguay (Pisces, Siluriformes, Loricariidae). Revue suisse de Zoologie, 92: 955-968.

Weber, C. 2003. The Hypostominae. Pp. 351-372. In: Reis, R. E., S. O. Kullander \& C. J. Ferraris Jr. (Eds.). Check list of the freshwater fishes of South and Central America. Porto Alegre, Edipucrs.

Zanata, A. M. \& W. M. Ohara. 2009. Jupiaba citrina, a new species from rio Aripuanã, rio Madeira basin, Amazonas and Mato Grosso States, Brazil (Characiformes: Characidae). Neotropical Ichthyology, 7: 513-518.

Zawadzki, C. H., C. Weber \& C. S. Pavanelli. 2008. Two new species of Hypostomus Lacépède (Teleostei: Loricariidae) from the upper rio Paraná basin, Central Brazil. Neotropical Ichthyology, 6: 403-412.

Submitted September 8, 2012 Accepted December 3, 2013 by Paulo Lucinda Published March 31, 2014 